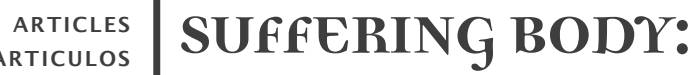 \\ Narrative tensions for a politics of the images in photojournalism
}

Copyright (c) 2015 SBPjor / Associação Brasileira de Pesquisadores em Jornalismo

\section{ANGIE BIONDI}

Universidade Tuiuti do Paraná, Brazil

ÂNGELA CRISTINA SALGUEIRO MARQUES

Universidade Federal de Minas Gerais, Brazil

\begin{abstract}
The aims of this article is to identify the elements that make the photographic image a narrative space that operates cultural codes that encloses their repertoire in order to compose interactional ways that define the experience of seeing suffering. We assume that the suffering body brought by the journalistic photograph, in the images here analyzed, do not really implies exploring forms of submission of the look to compassion, but invites to search some indications of resistance, subjectivation and revelations that can evidence how people photographed find ways to difficult the elaboration of subtitles to their faces and bodies creating dissonances and dissensus between their "appearance" and the narrative register (visual and verbal) of its exposition.
\end{abstract}

Keywords: Suffering. Body. Photojournalism. Politics. Narrative

\section{CORPO SOFREDOR: tensões narrativas para uma política das imagens no fotojornalismo}

RESUMO - O objetivo deste artigo é identificar os elementos que fazem da imagem fotográfica um espaço narrativo que maneja os códigos culturais que compreendem seu repertório a fim de compor modos interacionais que definem a experiência de ver o sofrimento. Partimos da observação de que o corpo sofredor trazido pela fotografia jornalística, nestes exemplares aqui analisados, implica menos em explorar formas de submissão do olhar à compaixão e mais buscar seus indícios de resistência, de subjetivação e revelações que possam evidenciar como os fotografados encontram maneiras de dificultar o legendamento de seus rostos e corpos criando dissonâncias e dissensos entre seu "aparecer" e o registro narrativo (visual e verbal) de sua exposição.

Palavras-chave: Sofrimento. Corpo. Fotojornalismo. Política. Narrativa

\section{CUERPO SUFRIDOR: tensiones narrativas para una política de las imágenes en el fotoperiodismo}

RESUMEN - El objetivo de este artículo es identificar los elementos que hacen de la imagen fotográfica un espacio narrativo que maneja los códigos culturales que entienden su repertorio para componer las maneras interaccionáis que definen la experiencia de ver el sufrimiento. A partir del comentario de que el cuerpo sufridor traído por la fotografía periodística, en estas unidades analizadas aquí, implica poco en explorar formas de sumisión de la mirada a la compasión y más en buscar sus indicaciones de resistencia, de subjetivación y las revelaciones que pueden evidenciar como las personas fotografiadas encuentran maneras de hacer difícil encontrar subtítulos para sus caras y cuerpos, creando disonancias disenso entre su "para aparecer" y el registro narrativo (visual y verbal) de su exposición.

Palabras clave: Sufrimiento. Cuerpo. Fotoperiodismo. Política. Narrativa 
Instead of regarding media photographs as a representative synthesis of the forms of knowledge on daily suffering in our society, the purpose of this text is to draw attention to the visual elements that compose the suffering body in its own image and that, many times, seems to resist the textual marks that attempt to frame it into certain all too reified identities. It is about observing the intensities of anguish inscribed in their crying faces, the imaginative unfoldings of the contractions of their bodies in pain, the articulation of gestures and silence while they crumple in torment making up, thus, a visual assembly characteristic of suffering brought by journalism.

Instituted in this combination of forces and forms, the suffering body, while being the main character of the image, enables a more accomplished observation on the way of being of a journalistic writing that seeks to superimpose itself over suffering through subtitles and texts that compose the narrative material. However, an approximation of the visual elements that form the suffering types brought by the clippings of such daily situations allows one to glimpse at the fact that the narrative arrangements are at the service of an aesthetics of suffering that summons a common way of feeling and thinking on the theme.

It is necessary to highlight the fact that the work of reflexion on such brief visual narratives is not restrained to mapping up an iconic repertoire, nor does it intend to establish any evolutive line of suffering along the years, but it seeks to observe "The effective ways of expressiong that are organized by photojournalism as models that establish parameters of apprehension and interaction with the espectator" (PICADO, 2011 , p. 54). What is at stake here is not the daily misfortune plainly portrayed, but to comprehend how such narrative set elaborated by photojournalism can constitute certain historicity of the fact itself, as well as proposing ways of experience of seeing.

When coming into a press photograph, a chain of transformations around reality has been put to action. Therefore, it is not the case to consider visual information only as a complement to written text, but to acknowledge its disposition in a wider process. "Newspaper is only an operator among the set of social-symbolic operators, being, apparently, only the last." (MOUILLAUD, 1997, p. 51).

In this text we seek to identify and position the elements that turn photographic image into a space of negotiation between cultural codes that comprehend their repertoire and the interaction modes that define the experience of seeing suffering, along with the spectators, making up for a certain politics of images.

\section{MODERN RESSONANCE OF SUFFERING DOCUMENTED IN IMAGES}

Photographs bring up the discussion around the exposition of suffering since modern period. A large part of the questions that supported the reflection developped around images that served to document diverse situations of catastrophe, attacks, disease and accidents still replicates a guide of thought in line with three much demarked points: a) the acknowledgement of socioeconomic 
inequality as the cause and producer of suffering; b) the request for responsive demands from the spectator; c) the accomplishment of ways of properly affective engagement, between sufferers and spectators. However, modern scenery in which such aspects would work intended to furnish a practical solution in order to minimize or eradicate suffering. At this point, photograph was considered as an ally in the process of transforming social reality, as it worked as priviledged instrument of denunciation and knowledge.

When criticizing the "politics of piety" enterprised in modern period, anchored on the acknowledgement of the asymetry inherent to the positions of sufferer and spectator, Boltanski highlights the fact that suffering was to be seen as a political happening, therefore constituted by and constituting the polis (BOLTANSKI, 1999, p. 16). However, the implications decurrent from a political practice based on compassion did not seem to be either sufficient nor adequate to this form of structural inequality. On the contrary, it did intensify the position of the sufferer as the object of anodyne denounciation and still connected itself to the maintenance of the status quo once such positions were kept in the passivity of distance.

At least two other connected aspects derive from such modern aspiration towards journalistic photograph whose effects one observes to this day. If, on the one hand there has been a profusion of photographic images in mass communication media, above all, press media, as authentic evidence of daily misfortune and malady (LEDO, 1998; SONTAG, 2004; FREUND, 2004) - on the other hand, the implications decurring from ostensive use of photos not only did constitute a great gallery of sufferers flattened as examples of diverse themes that composed ordinary suffering, but it was also the object of successive criticism whose remarks ranged from the exploitation of other people's disgrace to the responsibility for promoting a dull critical and affective sense in the spectators (ZELIZER, 2010; BARCELOS, 2009; MENDONÇA and BIONDI, 2011 ). The same purpose of objective realism that affirmed the place of photojournalism as detaining credibility ended up provoking certain crisis on what concerns its legitimacy'. However, even under such issues, photojournalism, as practical activity of information and communication, still takes over an important role on the ways of perceiving world realities configuring a complex field of visibility (MOUILLAUD, 1997).

Following up such incursions, photojournalism does still preserve certain anchoring on documental practice that gave origin to and keeps active the ressonances of modern longing for establishing bonds of cumplicty, belief and affection with the espectator, constituting a significant part of his/her daily interactions. The redefining of its protocols of documentation, however, now sits on other basis that propose the reformulation of issues still too dear to the relations sketched up between sufferer and spectator so as to reconfigure the experience with this universe of images.

Press photograph has not only come to present a more heterogeneous production on what concerns the management of this theme through differently elaborated forms of expression, but, 
above all, it defines a new zone of dispute and/or tension around the affective and subjective practices that such images themselves make possible. "The narrative capacity of visual images, inside the logic of photojournalism, redefines the status of contemporary history, pointing out the power of the happening as the synthesis of multiple times." (MAUAD, 2008, p. 171). In such context, it becomes necessary to investigate the expressive elements that characterize the situations of suffering and, not only seeing, but thinking the suffering body in its dispositions and arrangements in order to contemplate which appropriation competencies are operating and being requested in this interval in which the fact occurs, is reported and seen.

The observation of such (visual and textual) narrative sets brought up by journalism is the basis for establishing webs of meaning around suffering and sufferers, ones that may be accessed in different ways through the association to codes and discourses that update the perceptions on the theme, but also that produce ways of experience through images. Photojournalism has its reserved portion in a kind of practice responsible for producing, but also managing the visibility of suffering in the forms through which we nowadays have access to it. Following such context it becomes clear that it is not the objects the photographs - unique and singular, but the relations that can be articulated through them and their gadgets: this is what is constitutive of the experience of seeing suffering through press photographs.

\section{HOW TO NARRATE THE BODIES' SUFFERING}

In a set of photojournalistic images that report war situations, catastrophes, disease or poverty, the suffering inscribed in the bodies indicates how torment ${ }^{2}$ may be a form that allows one to notice the journalistic writing work that combines fact, expression and affection into a kind of narrative articulation that makes evident the tragic fortune of such populations. By highlighting the torment inscribed in these bodies, the image presents an association of pain with the fatidic event that strike the subjects in an inevitable, exceptional way, and a way of expression of the states of pain to which it refers (MENDONÇA and BIONDI, 2011).

In this set, a kind of punishment without blame, once without responsible subjects, is developed along visual elaborations that constitute this type of theme of suffering. To show the condition, to offer the action of pain in its tortuous process, to highlight the effect through its duration: that's how torment is presented in these bodies. Here, such themes as hunger, accident, catastrophe and disease present a kind of interwining of bodies in a kind of suffering that translates itself into ineluctable and constant fatalities.

What is offered in the short narratives of such sortilege are weakened, feeble, passive bodies, left to their own luck and resulting in characteristic visage of persistent pain that, in a constant and shrewd way, consume the forces and resistance of the bodies and their subjects. Delivered to destiny and its fatalities, the characters don't 
seem to summon or demand any kind of responsibility assumption nor propose to indicate anyone to be blamed, for they seem to be placed under the causalities of the world (BARCELOS, 2009).

The body, then, takes on an important point of inflexion in order to understand how suffering is brought up, elaborated and narratively summoned by photojournalism in as much as it concentrates a place of crossing forces of distinguished natures: those that characterize a subjective state, through emanation of anguish and pain, and also those that assume a certain condition as reference to the situation of suffering articulated by the assignment of negotiation of values, by the moral claims and power relationships at stake. It is the body who shows up as dynamic instance in which a doublefold nature reveals itself actively; the nature of sensations, of affective conjugations, source of internal excitement mobilized by the organic; as well as the nature or material organization, of concrete differentiation assumed by language, of the body structured and individualized by the codes of culture.

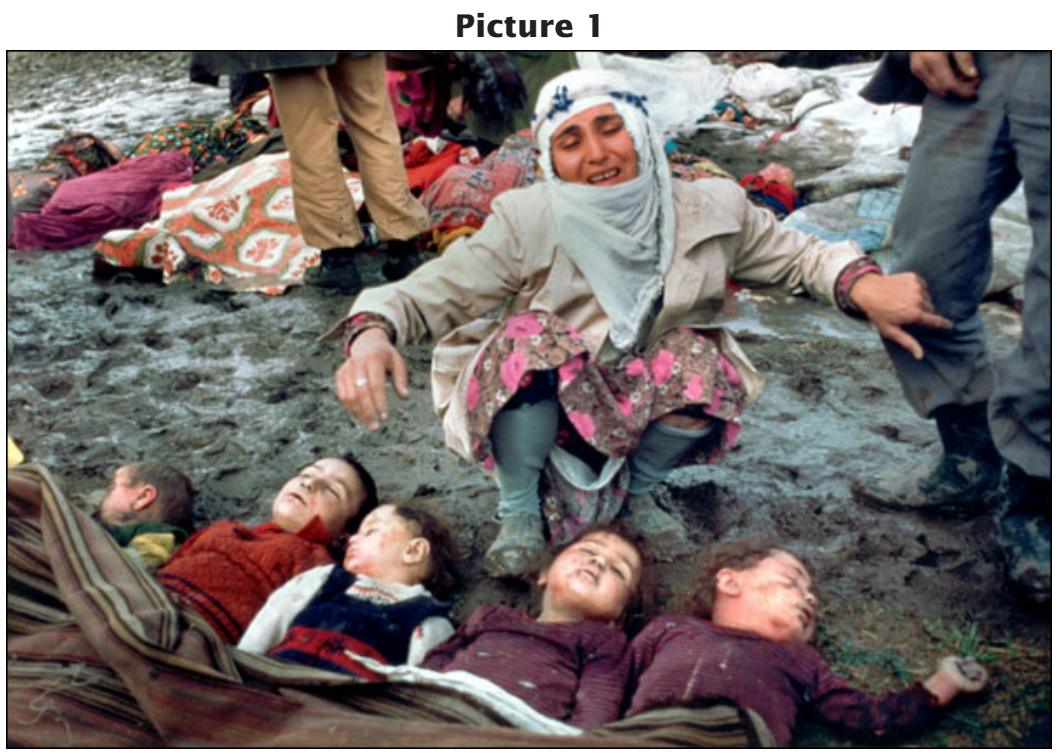

Photo: Mustafa Bozdemir, Turkey

Source: World Press Photo, 1983

The understanding of such dynamics is what allows one to trace a kind of cartography of the suffering body brought up by photojournalism through which a kind of axis is put to work, an axis in which the visible and readable aspects of suffering composes itself. Picture 1 offers the inconsolable of death. The loss of lives is presented through the female character: a woman crouching over a muddy ground finds the bodies of children laying down ahead. They would seem to be sleeping was it not for the articulation of other elements that compose the surroundings; their wrinkled and dirty 
clothes, their injuried faces, the disposition of the bodies in line and half covered, the mud.

The expression of pain fixed on the female face and the way how her body projects itself to the children - her arms seeking for support and one of the hands holding the leg of someone besides her - is what offers a vision of piety tensioned by the gestures of the body. The mother who projects herself to the body of her dead son, from the christian tradition, is rewritten in this disposition of suffering. The body in pain in this pietà by itself condenses the whole dramatic aspect brought up by the event. The female body who cries and wails underlines a pathos and places itself as the lócus of reverberation of the occurence, for it is the body crossed by the unpredictable catastrophe.

All the tragic dimension of the event features particularized in the pain of the central character (PICADO, 2011 , p.58). The expression on the face, the contraction of muscles, the leaning head, everything may be read as a gesture, as part components of the painful form.

When the human is the visual motif brought up by photograph, the body assumes the potentialized instance through which it shapes and/or stresses gestures, physiognomy and ambience in order to particularize the suffering and propose a way of experimenting this sight. It is not only a matter of framing, color and illumination, nor of documenting the occured fact. Human suffering, even in journalistic visuality, condenses a tension with any attempt at simple narration of what occured.

\footnotetext{
The examination of gesture texts allows one to distinguish not only the significant gestuality of gesticulation deprived of meaning as much as it also forces one to define the "gestural substance' as that which expresses itself thanks to this particular matter that is the human body while 'volume in movement'. The gestuality is no longer limited to the gestures of hands and arms or the expression in the face, but it makes itself a component part of human somatic behavior and does not constitute, at last, but one of the aspects of what one might call somatic language (GREIMAS \& COURTÉS, 2008, p. 237).
}

The constitution of this kind of visual economy of the body allied to the gestural forms as a writting of suffering is established in order to determine a pragmatics of visibility that does not dispense with a composition of ways of experience of seeing such images. "There where the photographer decides to point her camera an informative scene is born. This is so certain that, if we change the point of view or the scene we change the happening" (VILCHES, 1993, p. 141).

The body puts itself as frail, precarious element, delivered to the tragic fact that devastates life and, simultaneously, mobilizes the spectator in her resembling compassive attitude, for the body, in the catastrophe, is stricken by the pain of the loss of her common one.

It is one of the ways of portraying the body in torment that affects because it is linked to the different mobilizations of the act of looking.

"The happenings of media fit into shapes that are already constructions of space and time. The social space and time bring 
along marks that define areas and moments that prescribe its nature and its form to the happenings" (MOUILLAUD, 1997, p. 64). When the brief visual narratives of photojournalism bring to the foreground the human suffering through the proximity of the character inscribed by the framing or cut of the surroundings given by the disposition of the spectator in the angle of the scene, two orders join in the game: one which shows a fact that occured, that represents the real event, and another, which manifests the current relation of seeing given between the image and the spectator. This dynamics breaks through the extensive character which the spectator only "follows" a reading of real life situations brought up by photojournalism, and, in turn, the spectator now joins in a testimony of another's suffering. This expansion comes from the merging of a production proper to the journalistic ambit and its interlocutors.

The occurence of natural catastrophes that sickles lives, but also the diseases that martyr the subject or even hunger and misery that fall over individuals and whole populations suggests a fatidic character, accidental or exceptional, that manages to reverse that which would be proper to a history bearer of conditionings and variables in a social, economic or cultural temporality to the fatality of natural world of life. So it is that, in such visual narratives of daily life and its unhappiness it does not make itself necessary to assign any justification for such unhappy existences, for the production of blame is already instituted when it shows up implicit, concealed, subtle, but built in the very process of its journalistic visibility.

\section{SUFFERING AND PENURY: FOR A POLITICS OF PHOTOJOURNALISTIC IMAGES}

According to Rancière (2010), there is nowadays an attempt to evidence the fact that images and artistic works are political, above all due to the messages they supposedly wish to transmit, emphasizing domination stigmas, putting stereotypes into question, convoking the spectators to take on a critical posture, many times one of indignation and revolt. He affirms that politics may not be identified up from an instruction delivered by the images (and artistic works) for indignation, wonder, contestation of injustice, compassion or even horror.

One of the problems of associatiating politics and image (and even politics and art), according to him, is the belief in a previously established script for reading, interpreting and positioning face to the images. Rancière, however, affirms that the politics of images is not in the representative content expressed by them nor does it materialize as an instruction for looking the world and transform it through the gaining conscience of opressive forms.

The image cannot be mistaken for a guide for political action nor an instrument of massive conscientization. In this sense, Rancière (2010) proposes a way of comprehending images that scapes the assumptions according to which there is a necessary relation of 
cause-effect between what the image shows and the reception of the spectator, or that the intention of the artist is to provoke a sudden and deep change in the boards of meaning that orient the spectator's perception of the world. For that reason, the place of politics is not that in which one intends to use the representation for the correction of customs, values and actions. The politics of arts, according to him, implies a kind of taking distance and a suspension of any determinable relation between the intent of an artist and the spectator's looking (MARQUES, 2014).

Another recurring problem when it comes to the aproximation between politics and image consists on the perception that the image, in order to be political, must portray the injustices and social tribulations. On the contrary, Rancière stresses out that it is not enought to portray a social situation of penury and suffering or nurturing sympathy for the ones exploited and unassisted in order to make an image political. Not is it enough to evidence a sympathy for the subordinate and marginalized. According to him, it is wrong to think that a politics of image derives from "a way of representation that makes such situation inteligible as the effect of certain causes and that leads one to produce forms of conscience and affections that will modify it" (RANCIÈRE, 2009, p. 53). The image must not be reduced to a text that seeks to enlighten the causes and effects of justice. It cannot relate itself with the receiver in a kind of continuous bond, which associates the intents of the producer with the interpretations of the receiver in an immediate and pacific way.

An image cannot be considered political due to an assumed capacity of reconstituting social bonds, enabling the "inclusion" of subdued individuals or the redemption of those who suffer, and, thus, the eradication of the forms of oppression. "What is at stake is enabling the richness of the sensitive and the power of word and vision that are subtracted from the life and the scenery of precarious life to be restituted to it, so that they can be put to its reach" (RANCIÉRE, 2009, p. 60).

The politics must not be placed out of images, either - in the pretension of artists, in identified adaptations for representing the struggle of minority groups, in the repercussion and crossingovers of public spheres or in the construction of critical interpretative frames (despite such dimensions being indeed important).

If we insist in ascribing politicity to image taking into account an assumed character of inciding in concrete and practical way on injustices, we take the risk of adopting a posture, face to images, judging its pertinency or not to more just or plural representations, pointing out errors or distortions passable of occuring. Analysis that consider that image is only a thrigger for one to find the politics in another place do not take into consideration many of its asthetic, narrative and discursive elements.

Images, according to Rancière $(2010,2012)$, are political insofar as they may develop dissensus and rupture in homogeneous sceneries, ones of agreement and subjectification. The politics of images associates itself, thus, to the way how image may unveil potencies, reconfigure visibility regimes and put into question 
oppressive discursive orders. It is "the activity that reconfigures the sensible boards in the bosom of which one disposes of common objects, breaking with the evidence of a 'natural order' that defines the ways of making, the ways of saying and the ways of visibility" (HUSSAK, 2012, p. 103).

Under such aspect, an image is political once it ceases to foresee operations that influence the interpretation of what we see. Its potency is both in the images (sign materiality) and in the relations and operations that define it. Such operations influence the political characterization of what we see; it is the relations that define images, relations that establish themselves inside and outside visual ambit, which pre-configure enunciation, do and undo relations between the visible and the invisible, that which can be said and that which can be kept silent. As Rancière claims, "image is not simply what is visible. It is the gadget through which such visible is captured" (2007, p. 199).

If the politics of images is intrinsically tied to the way how operations constitute visibility regimes capable of regulating and constraining the "showing up" of the subjects, it seems intriguing to study such operations up from the registers and photojournalistic narratives disseminated in society and that, traditionally, follow standards that, at first, would make difficult the emergence of dissensus.

Our interest in this second part of the text is on observing the politics of images up from the analysis of how marginalized and suffering subjects, above all, empoverished women benefitted by Program Family Assistantship ${ }^{3}$, are photographed by journalistic media and gain visibility up from a logics of register that takes into consideration ingrained discourses on poverty, assistentialism, dependency, vulnerability and gender. It matters to see, up from photojournalistic images produced in the occasion of 10 years of the Program (2003-2013), if the bodies and faces of women photographed manage to resist the phrases, subtitles and narratives that accompany the images through "gestures, manners, ways, variations, resistance that, though miniscule they may seem, or even inapparent, express disagreement, dissensus, dissonance" (PELBART, 2003, p. 232).

If, on the one hand, photojournalism tends to portray the individuals by ascribing them enunciative places that come close to the logics of register and consensual subjectification (ascribing them only a name), we believe it is possible to identify marks of resistence and dissensus not only on the body of photographed individuals, but also in the dissonances between the texts (subtitles, indirect quotations, title of the article and its content) evidencing the tensions of becoming visible.

We observe how photojournalistic photographs capture and give visibility to bodies and narratives of poor women, so as to characterize a politics of life not as a question of management politics of the government, but as a matter connected to the invention of the polemical scene of "showing up", of appropriation and care giving to such exposition, and of interlocution in which one inscribes the gesture, the word and the body of the talking subject, in which the subject constitutes herself in a performatic, poetic and argumentative 
way up from the connection and disconnection between multiple names and ways of "presenting oneself" that define her.

Picture 2 illustrates an article produced by Marie-Claire magazine, in December 2012, on how women in the back lands of Brazil have been conquering autonomy, respect and resistance to masculine domination with the help from Program Family Assistantship. The text brings testimonies of women who separated from aggressive and violent husbands once they no longer needed to submit themselves in order to keep their homes. It reveals also how many women refused to supply the money gained from the program to their companions (the benefit card is entitled to the woman), rising against a culture of subservience and self-anihilation. Both the text and the narratives of the women interviewed are rich in examples of daily politization experience and the creation of dissensual spaces in domestic ambit. However, picture and subtitles do not portray, anyhow, such potency of emancipation.

\section{Picture 2}

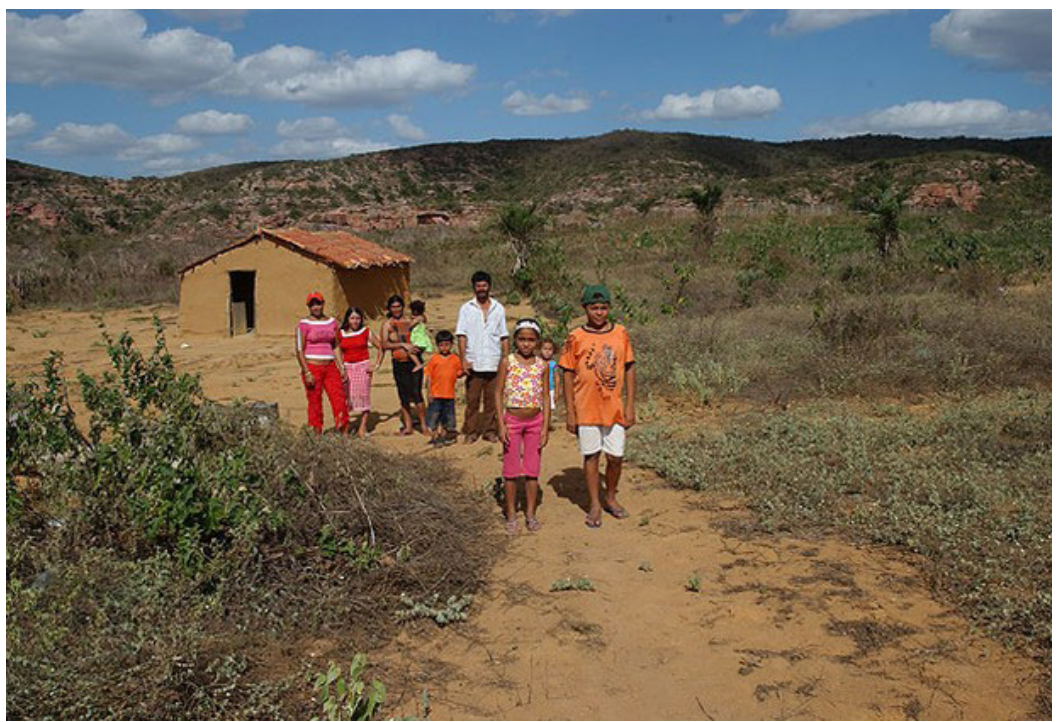

Photo: Archive/ Editora Globo

Source: SANCHES, Mariana. "Family-Assistantship and the feminist revolution in the Backlands", Marie Claire Magazine, 12/03/2012.

Subtitle: Money from Family-Assistantship brought the power of choice to the women of the backlands.

The stereotype picture places a numerous family in an arid landscape, isolated and dry, showing the suffering faces and bodies without much horizon for transformation. We may comprehend this image as a synthesis of a narrative that merges poverty, drought, Northeast Brazil and dependece, one originated from a representative 
system, one of relations established a priori, that defines its way of presentation and figuration in a specific narrative on poverty and poor people. The long shot does not allow the reader to perceive the faces, looks and bodies, due to the highlight of a long shot configuration, which only allows one to foresee a few issues: the mother and the eldest daughter appear on the background, behind every other members disposed in front of the house, in a position that suggests "brace", basis; the father appears at the center, with a light shirt on, indicating his hegemonic position in the family ambit; they are all dressed, what, on the contrary of the images mediated in the year of 2003 (in which children usually appear naked or half-naked), indicates consumption improvement. This picture can be considered emblematic of the register of the situation of those benefitted from 2003 to 2009, in average, always dissolving the bodies in landscapes, so that the conditions and possibilities of subjectivity appear as if determined by a previous geographic insertion, and by an ideology that remits northeastern woman to the domestic context, to motherhood and subservience to the husband.

The political potency of this image is certainly not found in its sensitive content, but in the operations of visibility that conjugate text and image so as to configure a "misfit" montage or linking that does not express contiguity or continuity between both expressive forms, but a gap, a rupture, a blank spot that offers a possibility of thinking on the plurality of ways of subjectivity - ways of being, existing, and taking position - that, many times, are not acknowledged by a consensual discoursive order that associates poverty to need and submission.

This power of making links is not the power of homogeneity - it is not to use a certain history in order to affirm suffering. It is, according to Rancière (2009), the power of heterogeneous, of immediate shock between three "lonelinesses": the loneliness of the shot, of the photo and of the words that speak of something completely different, in a context absolutely diverse. It is the shock of heterogeneous what supplies the common measure.

We are interested on studying how the operations of visibility conjugate words and images so as to make somebody appear in a polemic scene, in which the process of political subjectification brings up a multiple subject, bearing many "names" and passable of occupying places that, at first, were not ascribed to her. Such operations of visibility that configure image have, therefore, its dynamics assured by the singular drawing of interfaces and tensions between word and image. Thus, it is important to highlight that, according to Rancière,

(...) image does not belong exclusively to the visible. There a visible that does not produce image, there are images entirely contained in words. But the most common regime of image is that which brings to scene a relation between sayable and visible, a relation that plays at one time with its analogy and its dissimilarity. This relation does not demand at all that either term be materially present. The visible lets itself dispose in significative tropos, word exhibits a visibility that may make one blind. (RANCIÈRE, 2012, p. 15) 
Face to such considerations, the study of the politics of images in photojournalism must envolve a way of analysis able to conjugate word and image, one capable of allowing for a new way of reading such images. It is important to stress out that such readability be not mistaken for detailed description, nor with a kind of fragmentary analysis of its signs searching for what was not said. It defines itself, as remarked by DidiHuberman, by the mutual quest that words put on images and vice-versa, by the constant friction between the potencies of continuity and rupture:

(...) it is not a matter of submitting images to be decyphered,
but to place images and words in a relation of mutual disturb,
of ever renewed questioning as it goes back and forth. A critical
relationship. When such relationship is not constructed, when
images naturally convoke coincident words, or when words
spontaneously convoke the images that would correspond, then
we may that the images - as much as the words themselves
- were reduced to almost nothing worth of it: to stereotypes
(DIDI-HUBERMAN, 2011 , p. 45).

An analytic exercise of producing ways of readability of photojournalistic images (and of the operations of visibility and narrativity that configure such images) must acknowledge a double movement: a) the production of descriptions that evaluate marks, signs, gestures and ways of appearance of the portrayed individuals and $b$ ) the identification of the absence of seaming between discourse and image (the perfect fit between both leads to consensus) evidencing how images may grant to words their unnoticed readability. "An image can only expose its theme correctly if it implies on a relationship with the language that its own visuality is capable of rousing by disturbing it, by demanding it to restate itself, to put itself in cause" (DIDI-HUBERMAN, 2011 , p. 46).

The second image referring to the Program Family Assistantship was extracted from a special report, produced by Época Magazine, destined to gather testimonies of women benefitted by the Program so as to build an evaluative board of the changes promoted in their lives. Again, the spotlight is put on the inhabitants of Northeast Brazil, in the backlands of Paraíba. The characters interviewed are Josita Pereira da Silva, 49 yearsold, and her mother, Maria Pereira da Silva, 84, who is blind. They both received $\$ 60$ Reais monthly, at the time, from the program and claimed that nothing had changed: "It is not enough to make a living. It's enough to keep pushing on... We would prefer to gain our sustance from the land. But we can't. It only rains here when God wishes. So, almost everybody went out in the world. We're the only ones who stayed. I have no hope of improve. I know my destiny is to carry on with this life in such hardness. I only ask God to give me the strength to take care of my mother till her last day." (Josita) 


\section{Picture 3}

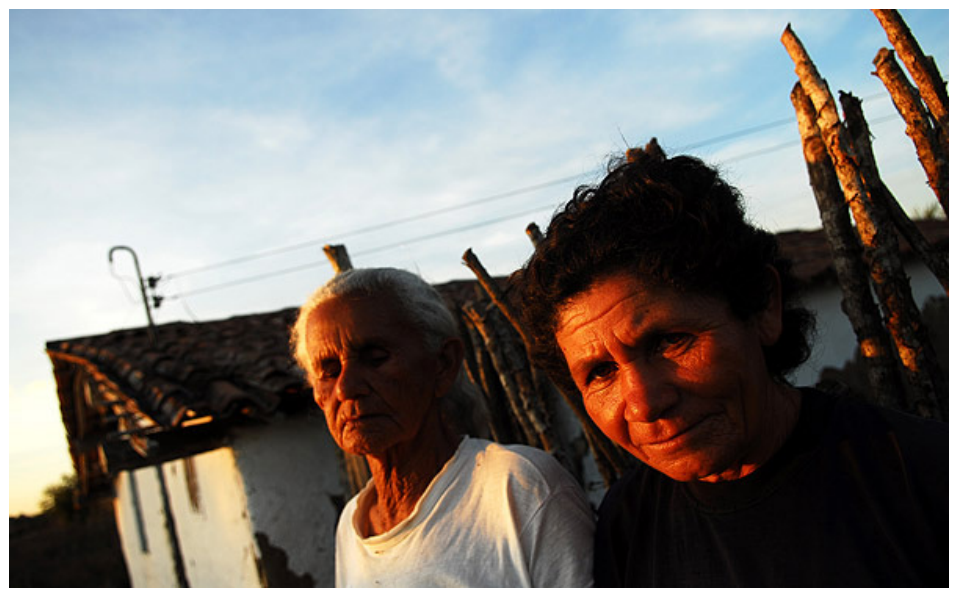

Photo: Leo Caldas/ Editora Globo

Source: BAHÉ, Marco. "The influence of Family-Assistanship in the life of people", Época Magazine, 11 1/07/2008

Subtitle: Josefa Pereira da Silva (49 years-old) and her mother, Maria Pereira da Silva (84) are attended by the Program Family-Assistantship but find that the situation did not change and will not change.

The composition of the photograph draws attention as it brings a slightly leaning background and the foreground marked by the light of dawn on the faces of the two women at front. Differently from the previous image, which valued more the landscape and imaginery associated to drought and hunger, this image puts on the spotlight the wrinkled and aging faces of the characters. The faces are partially lighted, indicating the proximity of night, suggering now a kind of protagonism of women and her reports.

Somehow, the light that hits the houses and the bodies of the women suggests the production of changes or widening of a horizon able to bring transformation. Somehow, the enlightened faces of the women photographed show they have resisted the phrases, subtitles and narratives that follow it, bringing tension to a consensual overlaying between text and image that associates the gesture of "reading", in images, postures and impostures that materialize in the face and may be able to "betray" the subtitle and journalistic narrative that insist on retrieving these women to "places" previously defined as that of "poor mothers depending on the assistance of the government". They offer the possibility of producing another scene of "apparence", transforming the coordinates of enunciation of life. "An image is never alone. It belongs to a gadget of visibility that regulates the status of the bodies represented and the kind of attention they deserve. The quest is to know the kind of attention that this or that gadget provokes" (RANCIÈRE, 2012, p. 96).

By pointing out to the regimes of visibility under which the images are produced and through which the present subjects and bodies have their ways of appearing being influenced by constraints typical of a discoursive 
regime that precedes them, Rancière makes clear that an inquiry into the politics of images must seek to observe the way how the bodies represented indicate possibilities of resistance, subversion and reinvention of the models of capture to which they are routinelly submitted.

\begin{abstract}
Let us say then that the question of objectivity of the real is tied to a hegemonic vision of the world, a vision of power, of those who detain the codes for decyphering the apparences. This way, journalistic photographic activity does not cease to be a way of attesting status quo by reproducing the dispositions inscribed in social structures. (GONÇALVES, 2009, p. 4).
\end{abstract}

The politicity of an image is that which produces, up from its own expressive means, "material reintermediations/rearrangements of the signs and images, in relationships between what we see and say, between what we do and what we can do" (RANCIÈRE, 2000, p. 62). This way, it may "reconfigure the map of the sensitive while disarranging the functionality of gestures and rhythms adapted to natural cycles of production, reproduction and submission" (idem). Put into another words, it is a potency that allows for the recombination of signs, being able to destabilize the evidences of the dominant discoursive registers and configures itself via the gesture of "playing with the ambiguity of similarities and the instability of dissimilarities, operating a local redisposition, a singular rearrangement of cyrcle images" (RANCIÈRE, 2012, p. 34).

One may think that there is, in the journalistic photographs that frame poor women, a fixation of the identity of the faces framed by the stereotype of "peripheral poor people" enhanced by the negative representation of the place they live and their gender. Many of these images may present points in common, on what concerns the features of the faces and the ways of showing them and posing to the photo, but, taking a careful look, it is possible to distinguish small gestures, inflexions and peculiarities that make way for such faces to question, interrogate, interpellate and convoke the spectators beyond a previously established place, that is, beyond indignation, piety and taking blame of the poor people and of their condemnation. In such cases, the face is something that supplies an important key for us to understand the singular testimony of these women, while at the same time their experience reveals unreacheable for us:

Photograph became an art, making the face of anomnymous speak twice: as mute testimonies of a condition directly inscribed in their traits, their clothes, their way of life; and as holders of a secret that we will never know, a secret stolen by the very image that brings us such faces (RANCIÈRE, 2012, p. 23).

The vision of a face photographed carries with it a relational and conversational intent, "once in it we see the accomplishment of the purpose of creating an impression of a special kind of actance, that of direct conversion (and, why not, also that of the political dimension of empathy)" (PICADO, 2009, p. 289). In the photo portrait, the summoning of the spectator promoted by the faces breaks through models and standards that will already be recognized favoring a kind of relationship with the 
spectator, one of the nature of the unexpected. When surrended by the look in the face of the one photographed, the spectator would turn into a kind of vicarious participant in the situation restored by the arrangement of the physiognomy in the image. According to him, "in the human appeal of the images that look at us, it is especially acute the meaning with which image exercises itself as a conversational genre" (PICADO, 2009, p. 290), featuring a face ever in between singularity and community.

But it is not always that the presence of the face and body of women on the foreground reveals a rupture with stereotype and framings that reduce subjective agency. Even though women are, from 2009 on, preferentially portrayed on the foreground of newspaper and magazine photographs, as "agents" who fight for a better life, the framing (of photo and text) often retrieves them to a situation of waiting for help (even divine help, sometimes) or opportunity (which depends on an interiorized perception according to which being successful in life is something that depends exclusively on the subject).

Going back to the question of singularity and stereotype of faces that come up in photograph, we consider it interesting to reflect on the observations that Didi-Huberman (2011, p. 67) develops on people without a face, that is, "the oppressed class, exposed to disappear or to be underexposed in consensual representations of history". According to him, people are either underexposed in the shadow of censorship to which they are subjected or overexposed in the light of their spectacularization. In both cases, they would be doomed to disappear:

\footnotetext{
Underexposition deprives us of the means to see, pure and simply, that which might be at stake. (...) But overexposition is not worth much more: too much light makes one blind. Peoples exposed to stereotype rumination of images are, they also, exposed to disappear. (...) If the peoples are exposed to disappear, this is also due to the fact of the construction of discourses due to which, ceasing to see anything, we may yet believe that everything remains accessible, everything remains visible and, as one uses to say, under control. (DIDI-HUBERMAN, 201 1, p. 41 and 45)
}

Are the women benefitted by Program Family-Assistantship peoples without faces, doomed to disappear due to the invisibility constructed by predominant consensual discourse of photojournalism? Or would it still be possible to restore, in photojournalistic registers, faces that instead of exposing "characters" appear precisely because they do not let themselves be reduced to discoursive contents given to inducted interpretation?

We seek to put into evidence some of the elements capable of pointing to a kind of resistance to the ready-made ways of life, the erasing and disappearing of subjects into narratives that only "fit" individuals in discoursive frameworks previously architectured, capturing their gestures, routines and bodies via consensual operations, constraints and submission of every kind. In this sense, the exposition and the appearance of body and face are capable not only to put worlds in opposition, but also to open them up and reopen them up, disclosing a political potentiality for dis-identification and rupture. 
When making a bet for the possibility of suffering faces and bodies to have not yet disappeared by the light of consensual discourse, we come from the idea that the look towards the suffering body exposed in journalistic photograph implies less in exploring its forms of disappearing and more in searching for the traces of resistence, subjectivation, revelations that may evidence how the ones photographed find ways to raise difficulties for the subtitling of their faces and bodies, by creating gaps, dissonances and dissensus between their "appearance" and the (visual and verbal) narrative register of their exposition.

*This paper was translated by Alice Medrado.

REFERENCES

BARCELOS, Janaina Dias. Fotojornalismo: Dor e Sofrimento. Estudo de caso do World Press Photo of the Year 1955-2008, 2009. Dissertação (Mestrado em Comunicação Social) - Universidade de Coimbra, Coimbra, 2009.

BOLTANSKI, Luc. Distant suffering: morality, media and politics. Cambridge: Cambridge University Press, 1999.

COURTÉS, J.; GREIMAS, A.J. Dicionário de Semiótica. São Paulo: Contexto, 2008.

DIDI-HUBERMAN, George. Coisa pública, coisa dos povos, coisa plural. In: NAZARÉ, Leonor; SILVA, Rodrigo (Org.). A República por Vir: Arte, Política e Pensamento para o Século XXI. Lisboa: Fondation Calouste-Gulbenkian, 2011 , p.41-70.

FREUND, Gisele. La fotografia como documento social. Barcelona: Gustavo Gili, 2004.

FOUCAULT, Michel. Vigiar e punir. Petrópolis: Vozes, 1977.

GONÇALVES, Sandra. Por uma fotografia menor no jornalismo diário contemporâneo. Revista E-Compós, Brasília, vol.12, n. 2, maio-agosto 2009.

HUSSAK, Pedro. Rancière: a política das imagens. Princípios, v.19, n.32, 2012, p.95-107.

LEDO, Margarita. Documentalismo fotográfico. Madrid: Cátedra, 1998.

MARQUES, Ângela. Política da imagem, subjetivação e cenas de dissenso. Discursos Fotográficos, v. 10, p. 61-86, 2014.

MAUAD, Ana Maria. O olho da história: fotojornalismo e história con- 
temporânea. ComCiência Revista Eletrônica de Jornalismo Científico. Disponível em http://www.comciencia.br/reportagens/memoria/12.shtml. Acesso em 20 janeiro 2013.

MENDONÇA, Carlos Magno Camargos; BIONDI, Angie. Dublê de corpo: a retórica do sofrimento no fotojornalismo. Contracampo (UFF), v. 22, p. 16-30, 2011.

MOUILLAUD, Maurice; PORTO, Sérgio Dayrell (Org). O jornal: da forma ao sentido. $2^{\mathrm{a}}$ ed. Brasília: Editora da Universidade de Brasília, 1997.

PELBART, Peter Pál. Vida capital: ensaios de biopolítica. São Paulo: Iluminuras, 2003.

PEREIRA, Carolina Sá Carvalho. O sofrimento em imagens: uma história entre a fotografia e a política, 2008. Dissertação (Mestrado em Comunicação) Universidade Federal do Rio de Janeiro, Rio de Janeiro, 2008.

PICADO, Benjamim. A Ação e a Paixão que se Colhem num Rosto: pensando os regimes de discurso do retrato humano no fotojornalismo. Revista Galáxia, São Paulo, n. 18, 284-299p., 2009.

. Sentido visual e vetores de imersão: regimes plásticos da implicação do espectador nas formas visuais do fotojornalismo. Revista Galáxia, São Paulo, n.22, 53-66p., dez. 2011.

RANCIÈRE, Jacques. Le Partage du Sensible: esthétique et politique. Paris: La Fabrique éditions, 2000.

Le travail de l’image. Multitudes, n.28, 2007, p.195-210.

El teatro de imágenes. In: AAVV, Alfredo Jaar. La política de las imágenes. Santiago de Chile: Editorial Metales pesados, 2008, p.69-89.

Política de Pedro Costa. In: Cem Mil Cigarros - os filmes de Pedro Costa. Lisboa: Orfeu Negro, 2009, p.53-63.

O espectador emancipado. São Paulo: Martins Fontes, 2010.

O destino das imagens. Rio de Janeiro: Contraponto, 2012.

SOUSA, Jorge Pedro. Uma histórica crítica do fotojornalismo ocidental. Chapecó: Argos, 2004.

SONTAG, Susan. Sobre fotografia. São Paulo: Companhia das Letras, 2004.

VILCHES, Lorenzo. Teoria de la imagem periodistica. Bercelona: Paidós, 1993.

ZELIZER, Barbie. About to die: how new images move the public. Oxford University Press, 2010. 
1 Jorge Pedro Sousa (2004, p. 61-69) brings up precise research on the movements that constituted photojournalism since the 20th century. In chapter VI of his better known book, A critical history of occidental photojournalism (our translation), he retrieves the main technical and social connections that invested on photojournalism as an autonoumous professional activity, though still presenting the nuances of a documental project.

2 Physical torment has been identified, initially, by Foucault (1977) as a punishment, a painful bodily sentence that had its basis in a corresponding quantification of the crime committed. As legitimate punitive technique up to the end of the 18th century and beginning of the 19 th century, torment was inflicted to the accused criminal according to sovereign sanctions. Modern rituals marked the change in the form of presentation of ordeal suffering, which gave way, then, to penalties of incorporeal nature. Torment dropped its ostensive aspect and came to be an ever more institutionalized and administrative procedure. This turned out to be a more subtle, technical and optimized fear politics on what concerns the disposal of the bodies and the costs, though not less efficient. Thus, a whole set of appreciative, prognostic and normative judgments was disseminated and penetrated the subject, ever more implied in this reception of penal sentence system (FOUCAULT, 1977, 23). What was at stake was a new inscription (and writting) of torment, which, even without harming the body directly, inhabited the body.

3 "Programa Bolsa Família": Federal program that provides monetary help for empoverished families in Brazil.

Angie Biondi is PhD in Social Communication, Universidade Federal de Minas Gerais (UFMG). Teacher of the Post-graduation Program in Communication and Languages at Universidade Tuiuti do Paraná

Ângela Cristina Salgueiro Marques is $\mathrm{PhD}$ in Social Communication, Universidade Federal de Minas Gerais (UFMG). Teacher of the Post-Graduation Program in Social Communication at UFMG. 